\title{
Rancangan Bangun Sistem Pakar Diagnosa Gejala Kecanduan Game Online Pada Remaja Menggunakan Metode Certainty Factor
}

\author{
Sony Kartika Wibisono ${ }^{1)}$, Amanah Tri Wulandari ${ }^{2)}$, Supriyatin ${ }^{3)}$ \\ 1)2)3) Program Studi Informatika, Universitas Harapan Bangsa, Purwokerto \\ ${ }^{1)}$ sonykartika@uhb.ac.id \\ 2)amanahwulandari285@gmail.com \\ ${ }^{3)}$ supriyatinupy707@gmail.com
}

\begin{abstract}
Online games are a type of game that provides its own pleasure for players, because it can be played not only alone (singleplayer), but can also be played with two or more people (multiplayer) from various places, and different countries. Because of that, many play online games continuously until they lose track of time, it can even lead to addiction. Therefore, an expert system is needed to diagnose symptoms of online game addiction as a means of overcoming the problem of online game addiction. This application developed aims to predict population growth rates by only analyzing the data using the Certainty Factor method, which is a method for managing uncertainty in a rule-based system. This method is able to handle the uncertainty of the answers found, namely when the expert cannot define the relationship between the symptoms and the cause with certainty, and the patient cannot feel the symptoms with certainty. From the results of this method, there are 3 types of online game addiction obtained from an expert, namely mild addiction (criteria between 0.1 to 0.39 ), moderate addiction (criteria between 0.4 to 0.79 ), and severe addiction (criteria between 0.8 to 1 ).
\end{abstract}

Keywords- Online Game, Expert System, Diagnosis, Certainty Factor

Intisari - Game online merupakan jenis permainan yang memberikan kesenangan tersendiri bagi pemainnya, karena dapat dimainkan tidak hanya sendiri (singleplayer), namun dapat juga dimainkan dengan dua orang atau lebih (multiplayer) dari berbagai tempat, dan negara yang berbeda. Karena hal itu, banyak yang memainkan game online secara terus menerus sampai lupa waktu, bahkan dapat menyebabkan kecanduan. Oleh karena itu, dibutuhkan sistem pakar untuk mendiagnosa gejala kecanduan game online sebagai sarana mengatasi masalah kecanduan game online tersebut. Aplikasi yang dikembangkan ini bertujuan untuk memprediksi tingkat pertumbuhan penduduk dengan hanya menganalisis data tersebut menggunakan metode Certainty Factor, yaitu metode untuk mengelola ketidakpastian dalam sisem berbasis aturan.
Metode ini mampu menangani ketidakpastian jawaban yang ditemukan yaitu ketika pakar tidak dapat mendefinisikan hubungan antara gejala dengan penyebab secara pasti, dan pasien tidak dapat merasakan gejala dengan pasti. Dari hasil metode tersebut terdapat 3 jenis kecanduan online game yang didapat dari seorang pakar yaitu kecanduan ringan (kriteria antara $0.1 \mathrm{~s} / \mathrm{d} 0.39$ ), kecanduan sedang (kriteria antara $0.4 \mathrm{~s} / \mathrm{d}$ 0.79), dan kecanduan berat (kriteria antara $0.8 \mathrm{~s} / \mathrm{d}$ 1).

Kata Kunci-Game Online, Sistem Pakar, Diagnosa, Certainty Factor

\section{PENDAHULUAN}

Perkembangan teknologi pada zaman sekarang sangat pesat. Berbagai macam jenis teknologi dapat kita jumpai di lingkungan sekitar kita. Salah satu perkembangan teknologi yang dapat kita rasakan adalah adanya gadjet. Teknologi yang diciptakan untuk mempermudah pekerjaan manusia ini banyak dampak positif maupun negatif. Dampak positif antara lain memudahkan manusia untuk berkomunikasi dengan orang-orang yang berada jauh dengan kita, dan dampak negatifnya antara lain melalaikan kita sampai membuat kecanduan pada game online yang ada pada aplikasi di gadjet tersebut.

Kecanduan online game adalah kesenangan saat bermain game karena memberi rasa kepuasan tersendiri, mulai dari segi grafis yang ditawarkan hingga cerita atau alur game yang membuat orang penasaran sehingga ada perasaan untuk mengulang lagi kegiatan menyenangkan yang ditawarkan ketika bermain online game [1].

Data Asosiasi Penyelenggara Jasa Internet Indonesia (APJII), bahwa pengguna internet untuk bermain online game di tahun 2017 sebesar 5,4\% dari 2500 responden dan tahun 2018 adalah sebesar 5,7 \% dari 5900 responden terdapat kenaikan pengguna internet untuk bermain online game yaitu sebesar 0,2 \%. Dari data di atas dapat

(c) 2021. Published by Fakultas Sains dan Teknologi - Universitas Harapan Bangsa

This is an open access article under the CC BY license (http://creativecommons.org/licences/by/4.0/)

http://ejournal.uhb.ac.id/index.php/IKOMTI 
mempresentasikan bahwa mahasiswa senang bermain game online. oleh karna itu perlunya perhatian khusus pada kasus tersebut agar mahasiswa tidak memiliki kecanduan online game dengan sistem pakar [2].

Dalam penerapanya sistem pakar mempunyai beberapa metode salah satunya adalah metode certainty factor, yaitu metode untuk mengelola ketidakpastian dalam sisem berbasis aturan. Implementasi metode certainty factor banyak digunakan dalam bidang kesehatan khususnya psikologi salah satu implementasi yang dapat diterapkan untuk melakukan diagnosis gangguan kepribadian. Metode ini mampu menangani ketidakpastian jawaban yang sering ditemukan yaitu ketika pakar tidak dapat mendefinisikan hubungan antara gejala dengan penyebab secara pasti, dan pasien tidak dapat merasakan suatu gejala dengan pasti sehingga pada akhirnya ditemukan banyak kemungkinan diagnosis. Dengan menggunakan pendekatan metode certainty factordalam melakukan diagnosis terhadap gangguan kepribadian diharapkan sistem mampu mendapatkan hasil diagnosis dengan cepat dan tepat.

\section{TINJAUAN PUSTAKA}

\section{A. Online Game}

Online game merupakan gabungan sebuah teknologi, sebuah permainan atau sebuah mekanisme untuk menghubungkan pemain satu dengan pemain lainnya dengan menggunakan koneksi jaringan internet baik melalui komputer atau smartphone. Online game adalah game yang berbasis media elektronik visual. Biasanya dapat mengakibatkan radiasi pada mata, sehingga matapun menjadi mudah lelah dan akan lebih mudah untuk sakit kepala. Online game pada saat ini berbeda dengan online game yang dimainkan untuk pertama kalinya yaitu pada tahun 1960, dimana komputer hanya bisa dipakai bermain online game untuk dua orang saja. Namun, pada saat ini online game bisa dimainkan oleh lebih dari dua orang atau secara bersamasama [3].

\section{B. Kecanduan Online Game}

Kecanduan atau addiction dalam kamus psikologi diartikan sebagai keadaan kebergantungan secara fisik pada suatu obat bius. Pada umumnya, kata kecanduan digunakan dalam konteks klinis dan diperhalus dengan perilaku berlebihan. Konsep kecanduan dapat diterapkan pada perilaku secara luas termasuk kecanduan teknologi komunikasi informasi.

Kecanduan game online merupakan salah satu bentuk kecanduan yang disebabkan oleh teknologi internet atau yang lebih dikenal dengan internet addictive disosder. Seperti yang disebutkan bahwa internet dapat menyebabkan kecanduan, salah satunya adalah Computer Game Addiction (berlebihan bermain game). Dari sini terliat bahwa game online merupakan bagian dari internet yang sering dikunjungi dan digemari sehingga mengakibatkan kecanduan yang memiliki intensitas yang sangat tinggi [4].

\section{Dampak Kecanduan Online Game}

Menimbulkan Adiksi (Kecanduan) Sebagian besar game yang beredar saat ini memang didesain supaya menimbulkan kecanduan para pemainnya. semakin seseorang kecanduan pada suatu game maka pembuat game semakin diuntungkan karena peningkatan pembelian gold/tool/karakter dan sejenisnya semakin meningkat. Tapi keuntungan produsen ini justru menghasilkan dampak yang buruk bagi kesehatan psikologis pemain game. Mendorong melakukan hal-hal negatif. Walaupun jumlahnya tidak banyak tetapi cukup sering kita menemukan kasus pemain game online yang berusaha mencuri ID pemain lain dengan berbagai cara. Kemudian mengambil uang didalamnya atau melucuti perlengkapannya yang mahal-mahal. Kegiatan mencuri ID ini biasanya juga berlanjut pada pencurian akun lain seperti facebook, email dengan menggunakan keylogger, software cracking dan lain-lain. Bentuk pencurian ini tidak hanya terbatas pada pencurian id dan password tetapi juga bisa menimbulkan pencurian uang - meskipun biasanya tidak banyak (dari uang SPP misalnya) dan pencurian waktu, misalnya membolos sekolah demi bermain game.

\section{Sistem Pakar}

Faktor kepastian (certainty factor) diperkenalkan oleh Shortliffle Buchanan. Certainty Factor $(C F)$ merupakan nilai parameter klinis yang diberikan MYCIN untuk menunjukkan besarnya kepercayaan. Dalam menghadapi suatu masalah sering ditemukan jawaban yang tidak memiliki kepastian penuh. Ketidakpastian ini bisa berupa probabilitas atau kebolehjadian yang tergantung dari hasil suatu kejadian. Hal ini sangat mudah dilihat pada system diagnosis penyakit, dimana pakar tidak dapat mendefinisikan tentang hubungan antara gejalaa dengan penyebabnya secara pasti, dan pasien tidak dapat merasakan suatu gejala dengan pasti pula. Sehingga, ditemukan banyak kemungkinan diagnosis.[5]

Faktor kepastian (certainty factior) merupakan cara dari penggabungan kepercayaan (belief) dan ketidakpercayaan (unbelif) dalam bilangan yang tunggal. Dalam certainty factor, data-data kualitatif direpresentasikan sebagai derajat keyakinan (degree of belief).

Tahapan dalam merempresentasikan data-data kaulitatif:

a. Kemampuan untuk mengekspresikan derajat keyakinan sesuai dengan metode yang sudah dibahas sebelumnya.

b. Kemampuan untuk menempatkan dan mengkombinasikan derajat keyakinan tersebut dalam sistem pakar.

Dalam mengekspresikan derajat keyakinan digunakan suaatu nilai yang disebut certainty factor(cf) untuk mengasumsikan derajat keyakinan seorang pakar terhadap suatu data [6]:

$\mathrm{CF}[\mathrm{H}, \mathrm{E}]=\mathrm{MB}[\mathrm{H}, \mathrm{E}]-\mathrm{MD}[\mathrm{H}, \mathrm{E}]$

Dimana:

- $\quad \mathrm{CF}$ adalah Certainty Factor (faktor kepastian) dalam hipotesis $\mathrm{H}$ yang dipengaruhi oleh fakta $\mathrm{E}$. 
- $\quad$ MB adalah Measure of Belief (tingkat keyakinan) adalah ukuran kenaikan dari kepercayaan hipotesis $\mathrm{H}$ dipengaruhi oleh fakta $\mathrm{E}$

- MD adalah Measure of Disbelief (tingkat ketidakyakinan) adalah kenaikan dari ketidakpercayaan hipotesis $\mathrm{H}$ dipengaruhi fakta $\mathrm{E}$

- $\quad$ E adalah Evidence (peristiwa atau fakta)

- $\quad \mathrm{H}$ adalah Hipotesis (dugaan)

Certainty Factor untuk kaidah dengan premis tunggal (single premis rule):

$\mathrm{CF}[\mathrm{H}, \mathrm{E}]=\mathrm{CF}[\mathrm{E}] * \mathrm{CF}[$ rule $]=\mathrm{CF}[\mathrm{user}] * \mathrm{CF}[$ pakar $]$

Certainty factor untuk kaidah dengan kesimpulan yang serupa (similary concluded rules) :

$\mathrm{CF}$ combine $\mathrm{CF}[\mathrm{H}, \mathrm{E}] 1,2=\mathrm{CF}[\mathrm{H}, \mathrm{E}] 2 *[1-\mathrm{CF}[\mathrm{H}, \mathrm{E}] 1]$

CF combine $\mathrm{CF}[\mathrm{H}, \mathrm{E}]$ old $3=\mathrm{CF}[\mathrm{H}, \mathrm{E}]$ old $+\mathrm{CF}[\mathrm{H}, \mathrm{E}] 3 *$ $[1 \mathrm{CF}[\mathrm{H}, \mathrm{E}] \mathrm{old}]$

\section{METODOLOGI}

Metode yang digunakan dalam penelitian ini adalah metode air terjun yang termasuk dalam salah satu metode SDLC (Software Development Life Cycle). Metode Waterfall adalah metode yang sering digunakan dalam pengembangan perangkat lunak dengan pendekatan secara sekuensial atau terurut mulai dari analisis, desain, pengodean, pengujian, dan pendukung [7] Berikut adalah gambaran dari metode Waterfall:
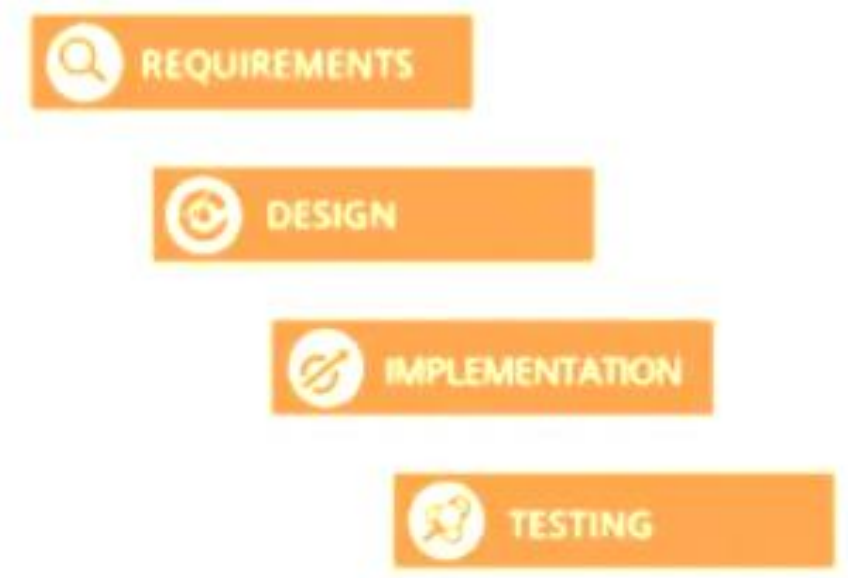

Gambar 1. Metode SDLC Waterfall

Menurut [7] Metode SDLC Waterfall dibagi menjadi beberapa tahapan yaitu:

\section{Requirements}

Tahapan metode waterfall yang pertama adalah mempersiapkan dan menganalisa kebutuhan dari software yang akan dikerjakan. Informasi dan insight yang diperoleh dapat berupa dari hasil wawancara, survei, studi literatur, observasi, hingga diskusi. Biasanya di dalam sebuah perusahaan, tim analis akan menggali informasi sebanyak banyaknya dari klien atau user yang menginginkan produk beserta dengan kebutuhan sistemnya. Selain itu, juga dapat mengetahui setiap batasan dari perangkat lunak yang akan dibuat.

\section{Design}

Tahap yang selanjutnya adalah pembuatan desain aplikasi sebelum masuk pada proses coding. Tujuan dari tahap ini, supaya mempunyai gambaran jelas mengenai tampilan dan antarmuka software yang kemudian akan dieksekusi oleh tim programmer. Untuk proses ini, akan berfokus pada pembangunan struktur data, arsitektur software, perancangan interface, hingga perancangan fungsi internal dan eksternal dari setiap algoritma prosedural. Tim yang mengerjakan tahap ini, biasanya lebih banyak menggunakan UI/UX Designer, atau orang yang memiliki kemampuan dalam bidang desain grafis atau Web Designer.

\section{Implementation}

Tahapan metode waterfall yang berikutnya adalah implementasi kode program dengan menggunakan berbagai tools dan bahasa pemrograman sesuai dengan kebutuhan tim dan perusahaan. Jadi, pada tahap implementasi ini lebih berfokus pada hal teknis, dimana hasil dari desain perangkat lunak akan diterjemahkan ke dalam bahasa pemrograman melalui tim programmer atau developer. Di dalam tahap pengembangan, biasanya dibagi lagi menjadi 3 tim yang memiliki tugas yang berbeda. Pertama ada front end (untuk client side), backend (untuk server side), dan full stack (gabungan antara front end dan backend). Selain itu, pada tahap ini juga dilakukan pemeriksaan lebih dalam terkait dengan modul yang sudah dibuat, apakah berjalan dengan semestinya atau tidak.

\section{Testing}

Pada tahap ini, akan dilakukan penggabungan modul yang sudah dibuat pada tahap sebelumnya. Setelah proses integrasi sistem telah selesai, berikutnya masuk pada pengujian modul. Yang bertujuan untuk mengetahui apakah perangkat lunak sudah sesuai dengan desain, dan fungsionalitas dari aplikasi apakah berjalan dengan baik atau tidak. Jadi, dengan adanya tahap pengujian, maka dapat mencegah terjadinya kesalahan, bug, atau error pada program sebelum masuk pada tahap produksi. Orang yang bertanggung jawab untuk melakukan testing adalah QA (Quality Assurance) dan QC (Quality Control).

Dalam penelitian ini menggunakan certainty factor. Faktor kepastian (certainty faktor) menyatakan kepercayaan dalam sebuah kejadian (fakta atau hipotesis) berdasarkan bukti atau penilaian pakar.

Nilai CF (rule) didapat dari interprestasi term dari pakar, yang diubah menjadi nilai CF tertentu sesuai tabel 1 [8]. 
Tabel 1 Tabel Intrepretasi Term Certainty Factor

\begin{tabular}{|l|c|}
\hline \multicolumn{1}{|c|}{ Uncrtain Term } & CF \\
\hline Definitely not (tidak pasti) & -1.0 \\
\hline $\begin{array}{l}\text { Almost certainly not } \\
\text { (hampir pasti tidak) }\end{array}$ & -0.8 \\
\hline Maybe not (mungkin tidak) & -0.4 \\
\hline Unknown (tidak tahu) & -2.0 to 0.2 \\
\hline Maybe (mungkin) & 0.4 \\
\hline $\begin{array}{l}\text { Probably (kemungkinan } \\
\text { besar) }\end{array}$ & 0.6 \\
\hline $\begin{array}{l}\text { Almost certainly (hampir } \\
\text { pasti) }\end{array}$ & 0.8 \\
\hline Definitly (pasti) & 1.0 \\
\hline
\end{tabular}

\section{HASIL DAN PEMBAHASAN}

Terdapat 3 jenis kecanduan online game yang didapat dari seorang pakar yaitu kecanduan ringan (kriteria antara 0.1 s/d 0.39), kecanduan sedang (kriteria antara $0.4 \mathrm{~s} / \mathrm{d}$ 0.79), dan kecanduan berat (kriteria antara $0.8 \mathrm{~s} / \mathrm{d} 1$ ), rule based dapat dilihat pada tabel 2 .

Tabel 2. Jenis Kecanduan Game

\begin{tabular}{|c|l|l|}
\hline Kode_Kecanduan & Tingkat Kecanduan & CF \\
\hline \multirow{2}{*}{ A } & Kecanduan Ringan & 0.3, \\
& & 0.15 \\
\hline \multirow{3}{*}{$\mathrm{B}$} & & 0.45 \\
& Kecanduan Sedang & 0.4 \\
& & 0.6 \\
$\mathrm{C}$ & \multirow{3}{*}{ Kecanduan Tinggi } & 0.65 \\
\hline & & 0.8 \\
& & 0.85 \\
\hline
\end{tabular}

Pada tabel 3 menjelaskan tentang kode gejala dan nama gejala dari tingkat kecanduan seseorang terhadap game online. Pada saat pengguna melakukan konsultasi gejala ini digunakan untuk pertanyaan-pertanyaan yang akan keluar.

Tabel 3. Kode Gejala Kecanduan Game

\begin{tabular}{|l|}
\hline \multicolumn{1}{|c|}{ GEJALA } \\
\hline E1 = memiliki keinginan bermain game setiap waktu \\
\hline E2 = pola hidup mulai tidak teratur atau terganggu \\
\hline E3 = mudah emosional \\
\hline $\begin{array}{l}\text { E4 = malas jika disuruh mengerjakan sesuatu selain } \\
\text { game }\end{array}$ \\
\hline E5 = sangat antusias jika ditanya mengenai game \\
\hline $\begin{array}{l}\text { E6 = tidak bisa konsentrasi saat melakukan suatu } \\
\text { pekerjaan }\end{array}$ \\
\hline E7 = terlihat sering mengantuk \\
\hline
\end{tabular}

E8 = rela mengeluarkan uang untuk bermain game

E9 = melupakan aktivitas septi makan, mandi, dll

E10 $=$ terputus dari kehidupan sosial

Pada tabel 4 menjelaskna kode gejala, nama gejala dan nilai $\mathrm{CF}$ yang digunakan untuk proses perhitungan dengan menentuka nilai certaintly factor.

Tabel 4. Kaidah Aturan

\begin{tabular}{|l|}
\hline \multicolumn{1}{|c|}{ RULES } \\
\hline IF memiliki keinginan bermain game setiap waktu \\
\hline AND pola hidup mulai tidak teratur atau terganggu \\
\hline $\begin{array}{l}\text { AND malas jika disuruh mengerjakan sesuatu selain } \\
\text { game }\end{array}$ \\
\hline THEN KECANDUAN RINGAN \\
\hline \\
\hline IF sangat antusias jika ditanya mengenai game \\
\hline $\begin{array}{l}\text { AND tidak bisa konsentrasi saat melakukan suatu } \\
\text { pekerjaan }\end{array}$ \\
\hline AND terlihat sering mengantuk \\
\hline AND mudah emosional \\
\hline THEN KECANDUAN SEDANG \\
\hline \\
\hline IF memiliki keinginan bermain game setiap waktu \\
\hline AND rela mengeluarkan uang untuk bermain game \\
\hline AND terputus dari kehidupan sosial \\
\hline AND melupakan aktivitas seperti makan, mandi, dll \\
\hline
\end{tabular}

Adapun logika metode certainty factor pada saat konsultasi, pengguna diberi pilihan jawaban yang masingmasing memiliki bobot seperti tabel 5 .

\section{Tabel 5. Bobot User}

\begin{tabular}{|c|l|c|}
\hline No & \multicolumn{1}{|c|}{ Jawaban User } & Bobot \\
\hline 1 & Tidak yakin & 0 \\
\hline 2 & Sedikit Yakin & 0.5 \\
\hline 3 & Cukup Yakin & 0.7 \\
\hline 4 & Yakin & 0.8 \\
\hline 5 & Sangat yakin & 1 \\
\hline
\end{tabular}

Nilai 0 menunjukan bahwa pengguna konsultasi menginformasikan bahwa seseorang tersebut tidak mengalami kecanduan seperti yang dinyatakan sistem. Semakin pengguna konsultasi yakin pada jenis kecanduan tersebut, maka semakin tinggi pula hasil presentase keyakinan yang diperoleh.

Proses perhitungan presentase keyakinan diawali dengan pemecahan sebuah kaidah yang memiliki premis majemuk, menjadi kaidah-kaidah yang memiliki premis tunggal. Kemudian masing-masing aturan baru dihitung CF nya, 
Vol. 2, No. 1, Mei 2021, pp. 17-23

sehingga diperoleh nilai $\mathrm{CF}$ untuk masing-masing aturan, kemudian nilai $\mathrm{CF}$ tersebut dikombinasikan.

Contoh, hasil interview dengan seorang gamer diperoleh hasil kriteria atau ciri-ciri sebagai berikut seperti tabel 5 .

1. Tidak bisa konsentrasi saat melakukan suatu pekerjaan kecuali bermain game

2. Sangat antusia jika ditanya tentang game

3. Terlihat sering mengantuk

4. Mudah emosional

Tabel 5. Analisis dengan Kasus

\begin{tabular}{|c|l|}
\hline kd_gejala & \multicolumn{1}{|c|}{ gejala } \\
\hline E6 & $\begin{array}{l}\text { tidak bisa konsentrasi saat melakukan } \\
\text { suatu pekerjaan }\end{array}$ \\
\hline E5 & $\begin{array}{l}\text { sangat antusias jika ditanya mengenai } \\
\text { game }\end{array}$ \\
\hline E7 & terlihat sering mengantuk \\
\hline E3 & mudah emosional \\
\hline
\end{tabular}

Dari hasil pengujian aplikasi dengan melakukan uji coba secara acak pada mahasiswa Fakultas Sains Dan Teknologi, seperti tabel 6 .

Tabel 6. Data Uji

\begin{tabular}{|c|c|c|c|}
\hline No & Nama & Gejala & Pakar \\
\hline 1 & Gamer_1 & $\begin{array}{l}\text { E1 } \\
\text { E2 } \\
\text { E4 }\end{array}$ & Ringan \\
\hline 2 & Gamer_2 & $\begin{array}{l}\text { E5 } \\
\text { E6 } \\
\text { E7 } \\
\text { E3 }\end{array}$ & Sedang \\
\hline 3 & Gamer_3 & $\begin{array}{l}\text { E5 } \\
\text { E6 } \\
\text { E7 } \\
\text { E3 }\end{array}$ & Sedang \\
\hline 4 & Gamer_4 & $\begin{array}{l}\text { E5 } \\
\text { E6 } \\
\text { E7 } \\
\text { E3 }\end{array}$ & Sedang \\
\hline 5 & Gamer_5 & $\begin{array}{l}\text { E5 } \\
\text { E6 } \\
\text { E7 } \\
\text { E3 }\end{array}$ & Sedang \\
\hline 6 & Gamer_6 & $\begin{array}{l}\text { E1 } \\
\text { E2 } \\
\text { E4 }\end{array}$ & Ringan \\
\hline 7 & Gamer_7 & $\begin{array}{l}\text { E8 } \\
\text { E10 } \\
\text { E }\end{array}$ & Berat \\
\hline 8 & Gamer_8 & $\begin{array}{l}\text { E8 } \\
\text { E10 }\end{array}$ & $\begin{array}{l}\text { Tidak } \\
\text { Teridenti } \\
\text { fikasi }\end{array}$ \\
\hline 9 & Gamer_9 & E5 & Sedang \\
\hline
\end{tabular}

\begin{tabular}{|c|c|c|c|}
\hline & & $\begin{array}{l}\text { E6 } \\
\text { E7 } \\
\text { E3 }\end{array}$ & \\
\hline 10 & Gamer_10 & $\begin{array}{l}\text { E10 } \\
\text { E9 }\end{array}$ & $\begin{array}{l}\text { Tidak } \\
\text { Teridenti } \\
\text { fikasi }\end{array}$ \\
\hline 11 & Gamer_11 & $\begin{array}{l}\text { E1 } \\
\text { E2 } \\
\text { E4 }\end{array}$ & Ringan \\
\hline 12 & Gamer_12 & $\begin{array}{l}\text { E8 } \\
\text { E9 }\end{array}$ & $\begin{array}{l}\text { Tidak } \\
\text { Teridenti } \\
\text { fikasi }\end{array}$ \\
\hline 13 & Gamer_11 & $\begin{array}{l}\text { E1 } \\
\text { E2 } \\
\text { E4 } \\
\end{array}$ & Ringan \\
\hline 14 & Gamer_12 & $\begin{array}{l}\text { E1 } \\
\text { E2 } \\
\text { E4 } \\
\end{array}$ & Ringan \\
\hline
\end{tabular}

Berikut ini hasil uji sampling dalam mengetahui seberapa kecanduan seseorang terhadap game online menggunakan $\mathrm{CF}$, seperti tabel 7 .

Tabel 7. Perhitungan Secara manual Gamer_2

\begin{tabular}{|c|c|c|c|c|c|}
\hline $\begin{array}{c}\text { kd_key } \\
\text { akinan }\end{array}$ & $\begin{array}{c}\text { keyakina } \\
\mathrm{n}\end{array}$ & $\begin{array}{c}\text { kd_ke } \\
\text { candua } \\
\mathrm{n}\end{array}$ & $\begin{array}{c}\text { Tingkat } \\
\text { kecandu } \\
\text { an }\end{array}$ & CF1 & CF2 \\
\hline 4 & yakin & $\mathrm{B}$ & sedang & 0.4 & 0.8 \\
\hline 3 & $\begin{array}{c}\text { cukup } \\
\text { yakin }\end{array}$ & $\mathrm{B}$ & sedang & 0.45 & 0.7 \\
\hline 4 & yakin & $\mathrm{B}$ & sedang & 0.6 & 0.8 \\
\hline 5 & $\begin{array}{c}\text { sangat } \\
\text { yakin }\end{array}$ & B & sedang & 0.65 & 1 \\
\hline
\end{tabular}

Perhitungan $\mathrm{CF}$ premis tunggal dan kombinasi $\mathrm{CF}$

1. CF Premis Tunggal

$$
\begin{array}{ll}
\text { CF User * CF } & \text { CF } 1.1=0,4 * 0,8=0,32 \\
\text { Pakar } & \text { CF } 1.2=0,45 * 0,7=0,315 \\
& \text { CF } 1.3=0,6 * 0,8=0,48 \\
& \text { CF } 1.4=0,65 * 1=0,65
\end{array}
$$

2.Kombinasikan CF $1.1 \mathrm{dg}$ CF 1.2

CF Combine (CF1, CF2)

CF Combine (CF1.1, CF1.2)

3.Kombinasikan CFold dg CF 1.3

CFcombine (CFold, CF1.4) 
Presentase Keyakinan

Dengan demikian perhitungan CF untuk user dengan tingkat keyakinan sistem 91,52\%

Pada Tahap ini menggambarkan aliran informasi pada sistem yang akan dikembangkan menggunakan activity diagram. Activity diagram menggambarkan berbagai jalur aktivitas dalam sistem yang sedang dirancang, bagaimana masing-masing aliran dimulai, keputusan yang mungkin terjadi, dan bagaimana aktivitas tersebut berakhir [9].

Diagram aktivitas atau Activity diagram menggambarkan workflow (aliran kerja) atau aktivitas dari sebuah sistem atau proses bisnis atau menu yang ada pada perangkat lunak. Yang perlu diperhatikan disini adalah bahwa diagram aktivitas menggambarkan aktivitas sistem bukan apa yang dilakukan pengguna, jadi aktivitas yang dapat dilakukan oleh system.

Pada activity diagram ini proses dari alur sistem pakar, seperti gambar 2.

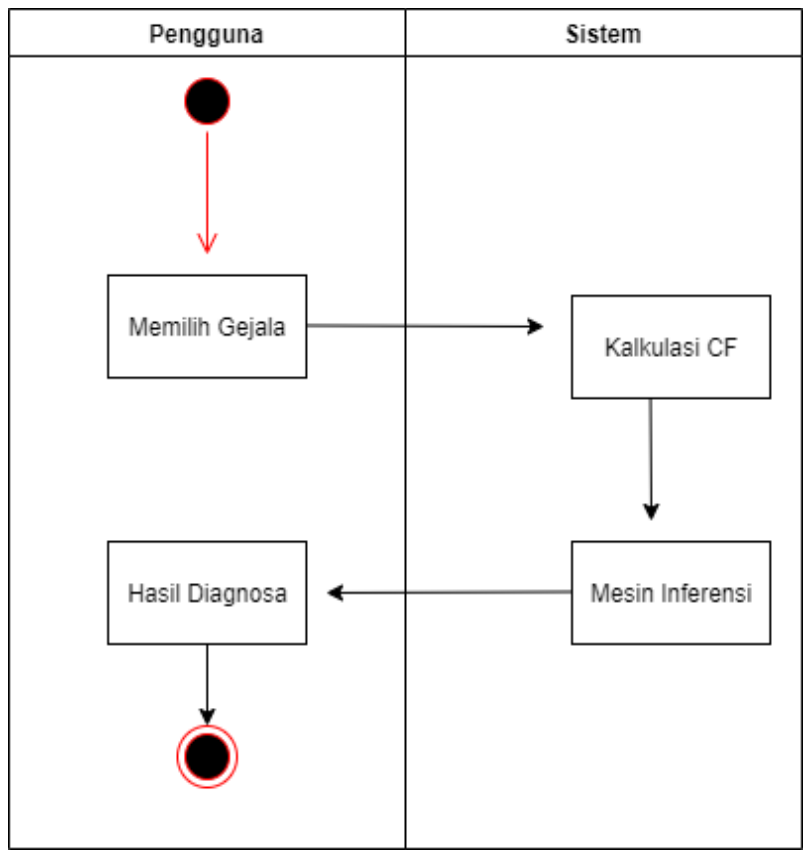

Gambar 2. Activity Diagram

Dari activity diagram tersebut dapat dijelaskan bahwa Pengguna dapat memilih gejala penyakit yang dialami kemudian sistem akan mengidentifikasi berdasarkan gejala yang diinputkan, selanjutnya hasil akan ditampilkan oleh sistem berdasarkan hasil kalkukasi yang dilakukan dengan menggunanakan certainty factor seperti pada contoh pembahasan sebelumnya.
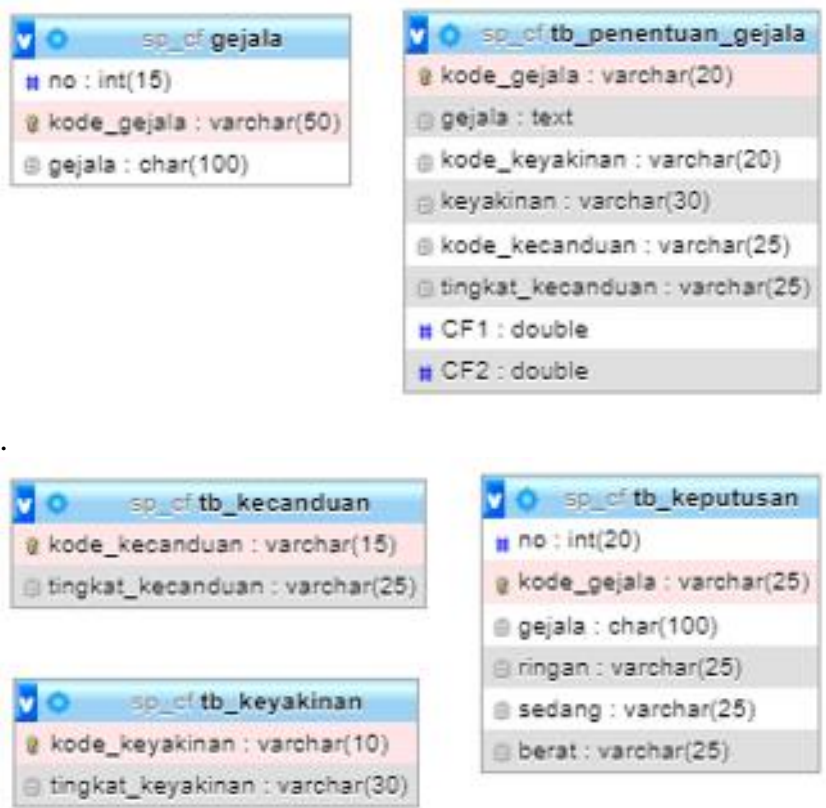

\section{Gambar 3. Entity Diagram}

\section{KESIMPULAN}

Dari perancangan dan implementasi yang telah dilakukan, ada beberapa kesimpulan yang dapat dikemukakan sebagai hasil dari skripsi ini, antara lain:

1. Metode Certainty Factor dapat diterapkan pada suatu sistem pakar yang mengidentifikasi tingkat kecanduan online game berdasarkan beberapa fakta yang berasal dari pakar dan input dari user (klien) pada saat user (klien) mengisi kuisioner.

2. Hasil identifikasi tingkat kecanduan online game dipengaruhi oleh nilai yang berasal dari jawaban kuisioner user (klien). Selain itu output berupa tingkat kecanduan juga mempengaruhi pemberian saran dari pakar.

3. Metode Certainty Factor dapat diimplementasikan pada sistem pakar untuk diagnosa tingkat kecanduan online game dengan tingkat akurasi sebesar $79 \%$ yang didapatkan dari pengujian 14 sampel data.

\section{REFERENSI}

[1] Sulistyorini, W. \& Sabarisman, M., 2017. Depresi: Suatu Tinjauan Psikologis. Sosio Informa, 3(2), pp. 153-164.

[2] [APJII], A. P. (2018). Profil Pengguna Internet Indonesia. Jakarta: Asosiasi Penyelenggara Jasa Internet Indonesia [APJII].

[3] Kustiawan, S.Pd., M. Or., A. A., \& Utomo, S.Pd., M. Or., A. W. (2019). Jangan Suka Online game: Pengaruh Online game Dan Tindakan Pencegahan. Magetan: AE Media Grafika. 
[4] Syahran, Ridwan. 2015. Ketergantungan Online Game dan Penanganannya. ISSN: 2443-2202. Palu: Jurnal Psikologi Pendidikan \& KonselingVol.1 No.1Juni 2015.

[5] Nurabsharina, A. P. \& Kosasih, R., 2020. Aplikasi Sistem Pakar Diagnosis Tingkat Depresi Pada Remaja Berbasis Android. Jurnal Ilmiah Informatika Komputer, 25(1), pp. 76-85.

[6] Andreyana, P. V., Piarsa, I. N., \& Buana, P. W. (2015). Sistem Pakar Analisis Kepribadian Diri dengan Metode Certainty Factor. Merpati, 3(2), 78-86.
[7] Pratiwi, H. (2019). Buku Ajar : Sistem Pakar. Kuningan: Goresan Pena.

[8] Sianturi, Ericksan. 2014. Sistem Pakar Diagnosa Gejala Kecanduan Game Online Dengan Menggunakan Metode Certainty Factor. ISSN: 2301-9425.Medan : Pelita Informatika Budi Darma Vol.VII No.3 Agustus 2014.

[9] R. Maulany, B. Hasan, A. G. Abdullah, and D. Rohendi, "Design of learning applications using the Rapid Application Development method," IOP Conf. Ser. Mater. Sci. Eng., vol. 1098, no. 2, p. 022090, Mar. 2021 